\title{
THE USE OF TOTAL LUMINESCENCE SPECTROSCOPY IN THE INVESTIGATION OF THE EFFECTS OF DIFFERENT RICE MANAGEMENT PRACTICES ON HUMIC SUBSTANCES OF A PLANOSOL ${ }^{(1)}$
}

\author{
Rodrigo Nogueira Olendzki ${ }^{(2)}$, Andréia Christina Ignácio ${ }^{(3)} \&$ \\ Antonio Salvio Mangrich ${ }^{(4)}$
}

\begin{abstract}
SUMMARY
In the Earth's carbon cycle, $\mathrm{C}$ stocks in the soil are higher than in vegetation and atmosphere. Maintaining and conserving organic $\mathrm{C}$ concentrations in the soil by specific management practices can improve soil fertility and productivity. The aim of this study was to evaluate the impact of agricultural management techniques and influence of water regime (flooded or drained) on the structure of humic substances by excitation/emission matrix fluorescence. Six samples of a Planosol (Planossolo by the Brazilian System of Soil Classification) were collected from a rice field. Humic substances (HS) were extracted from flooded and drained soil under different agricultural management techniques: conventional tillage, reduced tillage and grassland. Two peaks at a long emission wavelength were observed in the EEM spectra of HA whereas those of the corresponding FA contained a unique fluorophore at an intermediate excitation/emission wavelength pair (EEWP) value. The fluorescence intensity measured by total luminescence $\left(\mathrm{FI}_{\mathrm{TL}}\right)$ of $\mathrm{HA}$ was lower than that of the corresponding FA. A comparison of all samples (i.e., the HA values compared to each other) revealed only slight differences in the EEWP position, but the $\mathbf{F I}_{\mathrm{TL}}$ values were significantly different. In this soil, anoxic conditions and reduced tillage (little plowing) seem to favor a higher degree of humification of the soil organic matter compared with aerated conditions and conventional tillage.
\end{abstract}

Index terms: fulvic acid, humic acid, total luminescence spectroscopy.

\footnotetext{
(1) Recebido para publicação em julho de 2008 e aprovado em junho de 2009.

(2) Professor Titular da Coordenadoria de Química, Instituto Federal de Educação, Ciência e Tecnologia - Sul-Rio-Grandense, Campos de Pelotas. Praça Vinte de Setembro 455, CEP 96015-360 Pelotas (RS). E mail: rodrigao@pelotas.ifsul.edu.br

(3) Aluna do Curso de Bacharelado e Licenciatura em Química, Departamento de Química, Universidade Federal do Paraná UFPR. Caixa Postal 19081, CEP 81531-990 Curitiba (PR). Bolsista do CNPq. E-mail: deia_chris85@yahoo.com.br

(4) Professor Titular Sênior do Departamento de Química, UFPR. E mail: mangrich@quimica.ufpr.br
} 


\title{
RESUMO: USO DA TÉCNICA DE LUMINESCÊNCIA TOTAL NA INVESTIGAÇÃO DOS EFEITOS DE DIFERENTES MANEJOS DO SOLO PARA ARROZ SOBRE AS SUBSTÂNCIAS HÚMICAS DE UM PLANOSSOLO
}

\begin{abstract}
No ciclo do carbono terrestre, o solo contém maiores estoques de carbono que a vegetação e a atmosfera. Manter e conservar as concentrações de carbono orgânico no solo usando práticas de manejo pode aumentar sua fertilidade e produtividade. Por meio da espectroscopia de fluorescência pelo método da matriz excitação/emissão, avaliou-se o impacto de técnicas de manejo agrícolas e a influência do regime (inundado e drenado) sobre a estrutura das substâncias húmicas do referido solo. Seis amostras de um Planossolo hidromórfico foram coletadas de um campo com cultivo de arroz. As substâncias húmicas foram extraidas do solo, que estava sob condições inundadas e drenadas, sujeitas a diferentes técnicas de manejo agrícola: plantio convencional, plantio direto e campo nativo. Os espectros de matriz excitação/emissão dos ácidos húmicos apresentaram dois picos em comprimento de onda longo, enquanto aquelas dos correspondentes ácidos fúlvicos contiveram um único fluoróforo em valor intermediário do par comprimento de onda excitação/emissão. As intensidades de fluorescência, obtidas por luminescência total dos ácidos húmicos, foram menores do que as dos correspondentes ácidos fúlvicos. Uma comparação entre as amostras de ácidos húmicos revelou ligeiras diferenças nas posições dos pares comprimento de onda excitação/emissão, porém diferenças significativas foram observadas nos valores das intensidades de fluorescência. Nesse tipo de solo, as condições anóxicas e o manejo do plantio direto parecem favorecer um maior grau de humificação da matéria orgânica do solo, quando comparadas com as condições aeradas e o manejo do plantio convencional.
\end{abstract}

Termos de indexação: ácidos fulvicos, ácidos húmicos, espectroscopia de luminescência total.

\section{INTRODUCTION}

In the earth's carbon cycle, the soil contains larger $\mathrm{C}$ stocks than vegetation and the atmosphere, and is therefore considered the planet's major $\mathrm{C}$ store and main C sink (Swift, 2001). Carbon in the soil is considered sequestered because of the long period of time it can be stored and thus prevented from returning to the atmosphere. Many studies have focused on characterizing the most recalcitrant organic matter and identifying agricultural management and cultivation techniques that promote the increase of humic substances in soil (Rosell et al., 1989; Olk et al., 2000; Laird et al., 2001; Milori et al., 2002; Ding et al., 2002).

In Brazil, of the 47 Mha of soil farmed in 2005, 25 Mha were under reduced tillage management (little plowing). It should be noted that in tropical countries, in addition to minimizing soil disturbance, reduced tillage practices also involve an increased retention of plant residue and recycling. This is the main driving force towards rebuilding soil organic $\mathrm{C}$ (SOC) levels.

The southernmost state of Brazil, Rio Grande do $\mathrm{Sul}$, is one of the country's main producers of irrigated rice. In addition to various types of management, these soils are subjected to anaerobic flooding regimes and to aerobic drainage regimes during cultivation.
Fluorescence analysis can provide important comparative information about the structural and functional similarity and/or differences between HA and FA materials, which may be related to their degree of humification (Christl et al., 2000; Bertoncini et al., 2005).

Knowledge on HS fluorescence properties has been obtained from single-scan fluorescence data, mostly. Single-scan fluorescence emission spectra of humic substances (HS) normally have a single broad band whose maximum emission $\left(\lambda_{\max }\right)$ shifts according to the excitation wavelength $\left(\lambda_{\text {ex }}\right)$ utilized (Senesi, 1990; Sierra et al., 2000). At an identical $\lambda_{\text {ex }}$, FA fluoresces at higher intensities and shorter wavelengths than HA from the same origin (Belin et al., 1993; Sierra et al., 2000). Because laboratories use different excitation and emission wavelengths in HS studies, it is difficult to compare different studies, so no consistent fluorescence fingerprint of HS has been established so far (Sierra et al., 2005). The excitation/ emission matrix (EEM) can be used to minimize this problem, for it provides an overall view of all features existing within a selected spectral range (Sierra et al., 2005).

Three-dimensional fluorescence or total luminescence (TL) spectroscopy is a very powerful technique for characterizing and differentiating HA and FA in relation to their nature and origin (Bertoncini et al., 2005). 
Senesi et al. (1991) concluded that fluorescence properties such as fluorescence intensity (FI) and wavelength of the fluorescence emission maximum could be useful parameters for distinguishing between HA or FA from various sources.

The aim of this research was to evaluate the impact of agricultural management techniques and the effect of the water regime (flooded and drained) on the structure of the humic substances by excitation/ emission matrix fluorescence.

\section{MATERIALS AND METHODS}

\section{Site characterization}

The soil used in this study was taken from an Experimental Rice Field of Embrapa Temperate Climate in Pelotas, state of Rio Grande do Sul, Brazil $\left(31^{\circ} 52.0^{\prime} \mathrm{S}, 52^{\circ} 21.2^{\prime} \mathrm{W}, 13.2 \mathrm{~m}\right.$ asl). It was classified as Planossolo by the Brazilian System of Soil Classification, Planosol by WRB (FAO) and as Albaqualf by the USDA Soil Taxonomy. It contains $440 \mathrm{~g} \mathrm{~kg}^{-1}$ sand, $360 \mathrm{~g} \mathrm{~kg}^{-1}$ silt, and $190 \mathrm{~g} \mathrm{~kg}^{-1}$ clay. The soil chemical properties were: $\mathrm{pH} \mathrm{H}_{2} \mathrm{O}=4.8$; $\mathrm{pH}$ SMP $=5.8$; organic matter $=13.0 \mathrm{~g} \mathrm{~kg}^{-1} ; \mathrm{P}=$ $1.6 \mathrm{mg} \mathrm{kg}^{-1} ; \mathrm{K}=26.0 \mathrm{mg} \mathrm{kg}^{-1} ; \mathrm{Ca}=1.4 \mathrm{cmol}_{\mathrm{c}} \mathrm{kg}^{-1}$; $\mathrm{Mg}=1.0 \mathrm{cmol}_{\mathrm{c}} \mathrm{kg}^{-1}$, and $\mathrm{Al}=1.5 \mathrm{cmol}_{\mathrm{c}} \mathrm{kg}^{-1}$. The landuse history of the last 16 years was single rice cultivation (Oryza sativa L.) under conventional tillage (CT) and reduced tillage (RT). Six soil samples were taken from the $0-20 \mathrm{~cm}$ layer. Three samples were collected from flooded soil in April 2003 (under conventional tillage, reduced tillage, and grassland), and the other three from drained soil at the same place, in November 2003. Soil was sampled in all fields in multiple cores per plot, which were then pooled in each plot for subsampling.

\section{Extraction of humic substances}

Humic acids (HA) were extracted progressively three times, according to the method described by Cozzolino et al. (2000), and classified as HAFCT and HADCT (flooded and drained conditions managed by conventional tillage), HAFRT and HADRT (flooded and drained conditions managed by reduced tillage), and HAFG and HADG (flooded and drained no-tillage grassland).

The fulvic acids (FA) fractions were classified as described above (FADCT, FAFRT, FADRT, FAFRT, FADG, and FAFG) and analyzed in the dissolved state without further purification (Bertoncini et al., 2005).

The soil was dried and shaken for $24 \mathrm{~h}$ in a solution of $1 \mathrm{~mol} \mathrm{~L}^{-1} \mathrm{NaOH}$ and $0.1 \mathrm{~mol} \mathrm{~L}^{-1} \mathrm{Na}_{4} \mathrm{P}_{2} \mathrm{O}_{7}$ in $\mathrm{N}_{2}$ atmosphere. The alkaline extraction solution was separated from the insoluble part by centrifugation. HA samples were obtained from the alkaline extracts by lowering the $\mathrm{pH}$ to $\sim 1$ with $12 \mathrm{~mol} \mathrm{~L}^{-1} \mathrm{HCl}$ solution to separate precipitated HAs from the supernatant containing dissolved FA. The HAs were extensively purified by dissolution in a solution of $1 \mathrm{~mol} \mathrm{~L}^{-1} \mathrm{NaOH}$ under $\mathrm{N}_{2}$, followed by precipitation in concentrated $\mathrm{HCl}$. This procedure was repeated three times. The $\mathrm{HAs}$ were then shaken for $48 \mathrm{~h}$ in $0.5 \% \mathrm{HF} / \mathrm{HCl}$, dialyzed for three days against water, then frozen and lyophilized.

\section{Fluorescence spectra of humic and fulvic acids}

Fluorescence spectra were recorded from aqueous solutions of $100 \mathrm{mg} \mathrm{L}^{-1} \mathrm{HA}$ (Bertoncini et al., 2005) after overnight equilibration at room temperature, and adjustment to $\mathrm{pH} 9.2$ with $0.05 \mathrm{~mol} \mathrm{~L}^{-1} \mathrm{NaOH}$ under $\mathrm{N}_{2}$, and directly from the dissolved FA fractions, using a Hitachi model F-4500 luminescence spectrophotometer (Hitachi..., 2001). The TL spectra were obtained in the form of excitation/emission matrix (EEM) spectra (or contour maps) by scanning the wavelength emission over a 400 to $600 \mathrm{~nm}$ range, while the excitation wavelength was increased sequentially in $5 \mathrm{~nm}$ steps from 300 to $500 \mathrm{~nm}$. The EEM spectra were generated from TL spectral data using SigmaPlot 2000 software (SigmaPlot, 2000).

\section{RESULTS AND DISCUSSION}

The total luminescence spectra (TL) in the form of excitation/emission matrix spectra (EEM) of the humic acids (HA) and fulvic acids (FA) examined here are shown in figures 1 and 2 , respectively, while the excitation/emission wavelength pairs (EEWP) of the main peak maxima and the corresponding fluorescence intensity obtained from the TL spectra $\left(\mathrm{FI}_{\mathrm{TL}}\right)$ are listed in table 1.

The EEM spectra of HA contain two peaks at a long emission wavelength, whereas the spectra of the corresponding FA contain a unique fluorophore at an intermediate EEWP value. The $\mathrm{FI}_{\mathrm{TL}}$ of the HA were lower than that of the corresponding FA. Soil HAs are characterized by typical TL peaks at long wavelengths and low $\mathrm{FI}_{\mathrm{TL}}$ values (Bertoncini et al., 2005).

An increase in the extent of the $\pi$-electron system (i.e., the degree of conjugation) usually causes the fluorescence spectra to shift to longer wavelengths. This fact is illustrated by the series of linear aromatic hydrocarbons: naphthalene, anthracene, naphthacene and pentacene, which emit fluorescence in the ultraviolet, blue, green and red spectral regions, respectively (Valeur, 2001). The presence of oxygenand $\mathrm{N}$-containing functional groups in these systems also produces the same effect, whereas the presence of carbonyl and carboxyl substituents largely reduces FI (Senesi et al., 1991). 

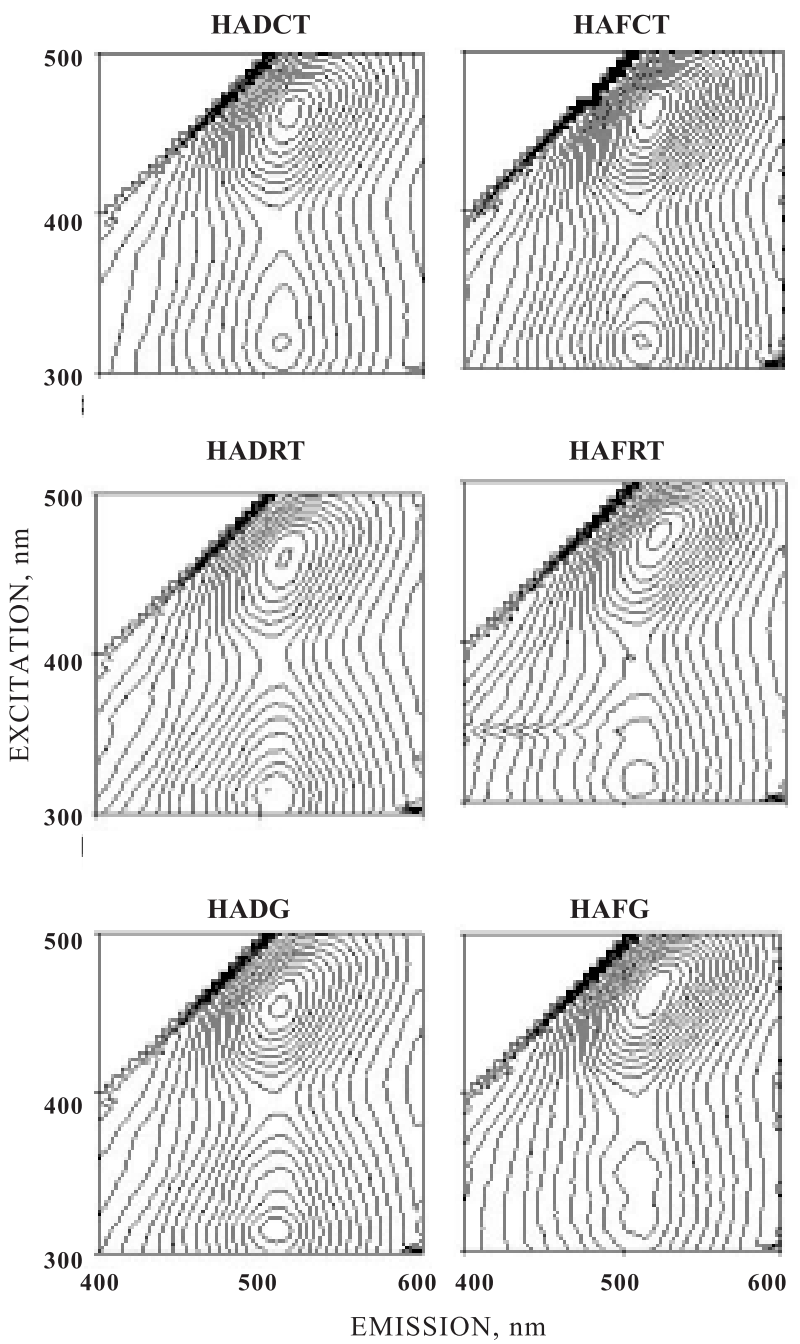

Figure 1. Total luminescence spectra of humic acids isolated from soil samples collected under drained *(HADCT, HADRT and HADG) and flooded conditions *(HAFCT, HAFRT and HAFG). As can be seen, HA samples display two peaks at a long emission wavelength.

* HADCT: humic acids from drained conventional tillage; HADRT: humic acids from drained reduced tillage; HADG: humic acids from drained grassland; HAFCT: humic acids from flooded conventional tillage; HAFRT: humic acids from flooded reduced tillage; HAFG: humic acids from flooded grassland.

In soil HA, our results indicate the presence of relative large-sized molecular components, rich in extended, linearly condensed aromatic ring systems and other unsaturated bond systems with a high degree of conjugation, bearing electron-withdrawing substituents (Senesi et al., 1991; Valeur, 2001; Bertoncini et al., 2005). Likewise, the use of absorbance ratios of $465-665 \mathrm{~nm}\left(\mathrm{E}_{4} / \mathrm{E}_{6}\right)$ was first proposed by Kononova (1961) and has been used to characterize the relative molecular size and degree of humification of SOM (Fooken \& Liebezeit, 2000). In general, the higher the molecular weight of HS, the lower is the $\mathrm{E}_{4} / \mathrm{E}_{6}$ ratio (Novotny et al., 1999).

On the other hand, a prevalence of TL peaks at short wavelengths and high $\mathrm{FI}_{\mathrm{TL}}$ values in soil $\mathrm{FA}$ were observed. These results may be ascribed to the presence of simple structural components of relative small molecular size, bearing electron donor

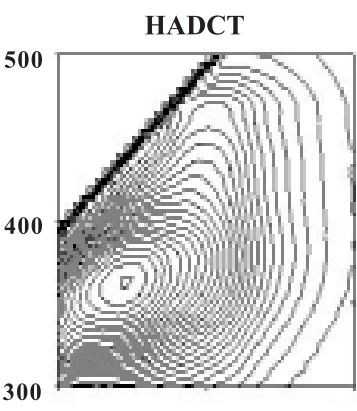

FADRT

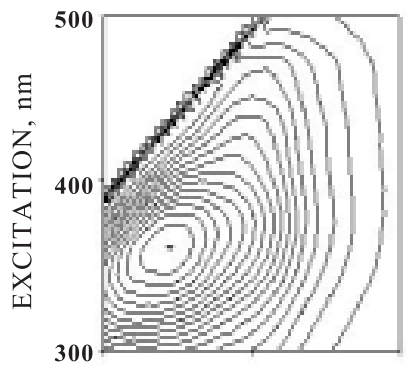

FADG

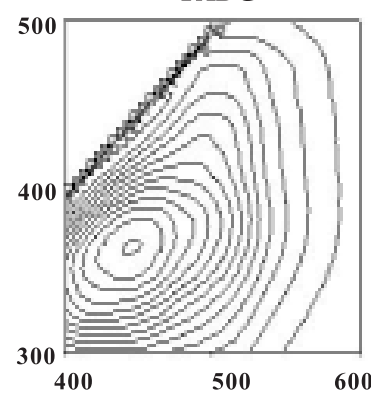

EMISSION, nm

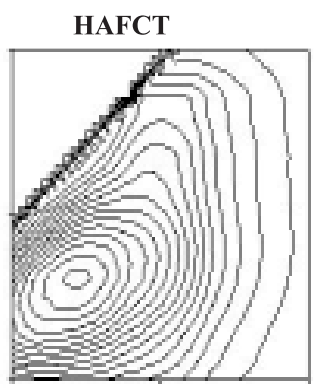

FAFRT

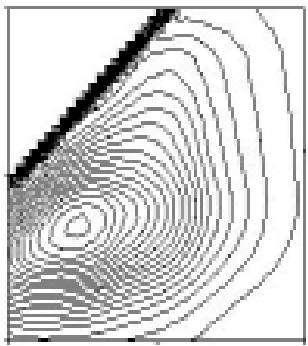

FAFG

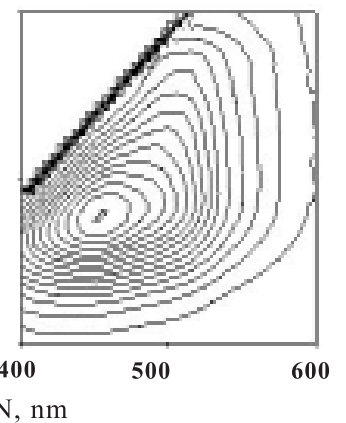

Figure 2. Total luminescence spectra of fulvic acids isolated from soil samples collected under drained *(FADCT, FADRT and FADG) and flooded conditions *(FAFCT, FAFRT and FAFG). Note that the FA samples display a unique fluorophore at an intermediate EEWP value.

* FADCT: fulvic acids from drained conventional tillage; FADRT: fulvic acids from drained reduced tillage; FADG: fulvic acids from drained grassland; FAFCT: fulvic acids from flooded conventional tillage; FAFRT: fulvic acids from flooded reduced tillage; FAFG: fulvic acids from flooded grassland. 
Table 1. Excitation/emission wavelength pairs (EEWP, $\mathbf{n m} / \mathbf{n m}$ ) of the main peak maxima in total luminescence spectra and the corresponding humic and fulvic acid fluorescence intensities $\left(\mathrm{FI}_{\mathrm{TL}}\right.$, arbitrary units)

\begin{tabular}{lrrrrr} 
& \multicolumn{2}{c}{ Humic acids } & & \multicolumn{2}{c}{ Fluvic acids } \\
\cline { 2 - 3 } & EEWP & FI FI $_{\mathrm{TL}}$ & & EEWP & FI $_{\mathrm{TL}}$ \\
\hline DCT & $460 / 520$ & 108 & & $365 / 445$ & 125 \\
DRT & $460 / 515$ & 64 & & $360 / 445$ & 118 \\
DG & $455 / 510$ & 91 & & $365 / 445$ & 98 \\
FCT & $460 / 520$ & 94 & & $360 / 445$ & 114 \\
FRT & $470 / 520$ & 55 & & $370 / 450$ & 115 \\
FG & $465 / 520$ & 62 & & $380 / 455$ & 75
\end{tabular}

(1) DCT: drained conventional tillage; DRT: drained reduced tillage; DG: drained grassland; FCT: flooded conventional tillage; FRT: flooded reduced tillage; FG: flooded grassland.

substituents, and to low levels of aromatic polycondensation and conjugated chromophores (Senesi et al., 1991; Valeur, 2001; Bertoncini et al., 2005). The presence of electron donor substituents in low molecular weight molecules can enhance the FI of these samples by increasing the probability of transition between the singlet and ground state (Senesi et al., 1991).

A comparison of all samples (i.e., the HA compared to each other) revealed only slight differences in the EEWP position, shifting to higher emission wavelengths in the samples collected under flooding. However, the $\mathrm{FI}_{\mathrm{TL}}$ values were not significantly different (Table 1).

Lower $\mathrm{FI}_{\mathrm{TL}}$ values were observed in $\mathrm{HA}$ samples collected under flooding than in those collected in the drained regime. These results suggest the presence of molecular components with a relatively large molecular size, a high level of aromatic polycondensation, and a high degree of humification in the samples collected during flooding (Bertoncini et al., 2005). It must be noted here that there is rotation of regimes, which seems be related with the tendency to increase or decrease the HA humification degree, i.e. the humification degree would increase under flooding and decrease under drained conditions. The presence of aerobic microorganisms responsible for the breakdown of aromatic rings in the drained regime could explain this fact.

With regard to the two types of management techniques, $\mathrm{FI}_{\mathrm{TL}}$ values were higher under conventional tillage (HACT) than reduced tillage (HART), indicating the lower range of molecular sizes in the CT samples and the presence of less humified components with hydroxyl, methoxy and amino substituents resulting from conventional tillage, in comparison with reduced tillage (Bertoncini et al., 2005).

\section{CONCLUSIONS}

1. The TL spectroscopy results provided evidence and information of the typical and distinct structural nature of the humic substances investigated here (HA and FA).

2. In this soil, the anoxic condition and reduced tillage (with little soil turning) seemed to favor a higher degree of SOM humification than the aerated condition and conventional tillage.

3. Reduced tillage (HA) samples contained more carbonyl or carboxyl groups, as evidenced by the lower $\mathrm{FI}_{\mathrm{TL}}$ values than found in conventional tillage and grassland samples (no tillage).

\section{ACKNOWLEDGEMENTS}

The authors gratefully acknowledge the funding and practical support of the Brazilian agencies and institutions UFPR, CEFET-RS, EMBRAPA/CPACT, CNPq, and Fundação Araucária.

\section{LITERATURE CITED}

BELIN, C.; QUELLEC, C.; LAMOTTE, M.; EWALD, M. \& SIMON, P.H. Characterization by fluorescence of the dissolved organic matter in natural water. Application to fractions obtained by tangential ultrafiltration and XAD resin isolation. Environ. Technol., 14:1131-1144, 1993.

BERTONCINI, E.I.; D’ORAZIO, V.; SENESI, N. \& MATTIAZZO, M.E. Fluorescence analysis of humic and fulvic acids from two Brazilian Oxisols as affected by biosolid amendment. Anal. Bioanal. Chem., 381:1281-1288, 2005.

COZZOLINO, A.; CONTE, P. \& PICCOLO, A. Conformational changes of humic substances induced by some hydroxy, keto-, and sulfonic acids. Soil Biol. Biochem., 33:563571,2001

CHRISTL, I.; KNICKER, H.; KÖGEL-KNABNER, I. \& KRETZSCHMAR, R. Chemical heterogeneity of humic substances: Characterization of size fractions obtained by hollow-fibre ultrafiltration. Eur. J. Soil Sci., 51:617625,2000

DING, G.; NOVAK, J.M.; AMARASIRIWARDENA, D.; HUNT, P.G. \& XING, B. Soil organic matter characteristics as affected by tillage management. Soil Sci. Soc. Am. J., 66:421-429, 2002

FOOKEN, U. \& LIEBEZEIT, G. Distinction of marine and terrestrial origin of humic acids in North Sea surface sediments by absorption spectroscopy. Marine Geol., 164:173-181, 2000 .

HITACHI HIGH-TECHNOLOGIES CORPORATION. Copyright $^{\odot}$ Hitachi High-Technologies Corporation. 3.ed. Japan, 2001. 
KONONOVA, M.M. Soil organic matter; its nature, its role in soil formation and in soil fertility. Oxford, Pergamon Press, 1961.

LAIRD, D.A.; MARTENS, D.A. \& KINGERY, W.L. Nature of clay-humic complexes in an agricultural soil : I. Chemical, biochemical, and spectroscopic analyses. Soil Sci. Soc. Am. J., 65:1413-1418, 2001.

MILORI, D.M.B.P.; MARTIN-NETO, L.; BAYER, C.; MIELNICZUK, J. \& BAGNATO, V.S. Humification degree of soil humic acids determined by fluorescence spectroscopy. Soil Sci., 167:739-749, 2001.

NOVOTNY, E.H.; BLUM, W.E.H.; GERZABEK, M.H. \& MANGRICH, A.S. Soil management system effects on size fractionated humic substances. Geoderma, 92:87-109, 1999.

OLK, D.C.; BRUNETTI, G. \& SENESI, N. Decrease in humification of organic matter with intensified lowland rice cropping: A wet chemical and spectroscopic investigation. Soil Sci. Soc. Am. J., 64:1337-1347, 2000.

ROSELL, R.A.; ANDRIULO, A.E.; SCHNITZER, M.; CRESPO, M.B. \& MIGLIERINA, A.M. Humic acids properties of an Agriudoll soil under 2 tillage systems. Sci. Total Environ., 81:391-400, 1989.
SENESI, N. Molecular and quantitative aspects of the chemistry of fulvic acid and its interactions with metal ions and organic chemicals. Part II. The fluorescence spectroscopy. Anal. Chim. Acta., 232:77-106, 1990.

SENESI, N.; MIANO, T.M.; PROVENZANO, M.R. \& BRUNETTI, G. Characterization, differentiation, and classification of humic substances by fluorescence spectroscopy. Soil Sci., 152:259-271, 1991.

SIERRA, M.M.D.; GIOVANELA, M.; PARLANTI, E. \& SORIANO-SIERRA, E.J. Fluorescence fingerprint of fulvic and humic acids from varied origins as viewed by single-scan and excitation/emission matrix techniques. Chemosphere, 58:715-733, 2005.

SIERRA, M.M.D.; GIOVANELA, M. \& SORIANO SIERRA, E.J. Fluorescence properties of well-characterized sedimentary estuarine humic compounds and surrounding pore waters. Environ. Technol., 21:979-988, 2000.

SIGMAPLOT 2000 for windows, Version 6.00. Copyrightc, SPSS Inc., 1986-2000.

SWIFT, R.S. Sequestration of carbon by soil. Soil Sci., 166:858$871,2001$.

VALEUR, B. Molecular fluorescence: Principles and applications. New York, Wiley, 2001. 58p. 